\title{
ATIPIKUS MUNKAVÉGZÉSI FORMÁK SPORTESEMÉNYEKEN
}

\section{ATYPICAL WORK AT SPORTING EVENTS}

\author{
Gősi Zsuzsanna ${ }^{1^{*}}$ \\ ${ }^{1}$ Egészségfejlesztési és Sporttudományi Intézet, Pedagógia és Pszichológiai Kar, Eötvös Loránd \\ Tudományegyetem, Magyarország \\ https://doi.org/10.47833/2020.2.ECO.003
}

\section{Kulcsszavak:}

atipikus foglalkoztatás

sportesemény

önkéntesség

\section{Keywords:}

atypical work

sporting event

volunteering

\section{Cikktörténet:}

Beérkezett 2019. szept. 21.

Átdolgozva 2019. okt. 31.

Elfogadva 2019. nov. 10.

\section{Összefoglalás}

A magyar sportszektor az elmúlt években látványos fejlődésen ment keresztül. Ezzel párhuzamosan egyre több nemzetközi és hazai sportesemény kerül megrendezésre. Ezeken az eseményeken többféle atipikus foglalkoztatási formával találkozhatunk. A tanulmányban leggyakoribb atipikus formák kerülnek bemutatásra: az önkéntesség, a játékvezetőkkel és versenybírókkal kapcsolatos kérdések, és az egyszerüsített foglalkoztatás.
Abstract
Hungarian sport financing has been transformed since 2010 and the revenues of sports organizations have increased. The number of international and domestic sports events in Hungary are constantly increasing, where many atypical forms of employment (non-standard forms of employment) can be seen. This article describes the most common atypical forms of employment like volunteering, employment of referees, simplified employment.

\section{Bevezetés}

A magyar sportszektor köszönhetöen annak, hogy 2010 óta a kormányzat stratégiai ágazatként kezeli jelentős átalakuláson ment keresztül. A sportszövetségek és a sportegyesületek bevétele a többszörösösére emelkedett. Megnövekedett mind a nemzetközi, mind a hazai rendezésű sportesemények száma. Ennek köszönhetően egyre több és több munkavégző található a szektorban.

Mit is jelent valójában az atipikus munkavégzés. Ezt lekönnyebben a tipikus munkaviszony meghatározásával írható le. A hagyományos, vagy más néven tipikus munkaviszony a munkaeröpiacon leginkább elterjedt alkalmazotti munkavégzésre utal. A munkavállaló feladatai jól körül határolhatók, folyamatosan visszatérnek ismétlődnek, napi nyolcórás munkavégzés keretei között valósulnak meg. [17] Atipikus foglalkoztatásnak pedig az tekinthető, amely valamilyen szerkezeti elemben eltér a hagyományos foglalkoztatás elemeitöl. Az eltérés négy különbözö tényező mentén határozhatjuk meg: térbeli, időbeli, élethelyzet szerinti és munkajogi. [9, 14] Ezek a foglalkoztatási formák lehetőséget adnak a munkaerő hatékony és rugalmas alkalmazására. A szervezetek esetében javítja versenyképességet és csökkentheti a munkaerő költséget. [13]

A sportszektorban a foglalkoztatási formák azonban gyakran eltérnek a tipikus foglalkoztatástól. [15] Az eltérések egyik oka az időbeosztás sajátossága: az utánpótlás és a

\footnotetext{
* Kapcsolattartó szerző. E-mail cím: gosi.zsuzsanna@ppk.elte.hu
} 
szabadidő sportban a délutáni edzések, valamint az amatőr és professzionális sportban hétvégén megrendezett versenyek, mérkőzések. A másik indok a finanszírozásban, pontosabban annak ütemezésében keresendő. Az 1. táblázatban a Magyar Kosárlabdázók Országos Szövetségének létszámadatai láthatóak, ami tükrözi a tipikus és atipikus formák közötti nagyságrendi eltérést.

1. táblázat A Munkavégzők létszáma a Magyar Kosárlabdázók Országos Szövetségénél (fö)

\begin{tabular}{|l|c|c|c|c|}
\hline \multicolumn{1}{|c|}{ Megnevezés } & $\mathbf{2 0 1 2}$ & $\mathbf{2 0 1 4}$ & $\mathbf{2 0 1 6}$ & $\mathbf{2 0 1 8}$ \\
\hline Szellemi foglalkozásúak & 10 & 19 & 22 & 29 \\
\hline Fizikai foglalkozásúak & 0 & 0 & 0 & 0 \\
\hline Megbízottak & 444 & 701 & 942 & 1100 \\
\hline
\end{tabular}

Forrás: MKOSZ számviteli beszámolók, saját szerkesztés

A tanulmányban sportversenyek területén legjellemzöbb három atipikus foglalkoztatási formára fókuszálunk: az egyszerüsített foglalkoztatás, játékvezetők versenybírók foglalkoztatása, valamint az önkéntesek részvétele. A három közül csak egy kapcsolódik szorosan a munka törvénykönyvében nevesített formákhoz ez az egyszerüsített foglalkoztatás. A másik két jogviszony részletes szabályozást más jogforrásokban találhatjuk meg. Módszerként a dokumentumelemzést választottuk. A feldolgozás során áttekintésre kerültek a speciális munkavégzési formákra vonatkozó törvények és szabályozók. Ez az elemzés került kiegészítésre a sportszektorra jellemző tipikus formákkal, és jellemző adatokkal.

\section{Versenybírók, játékvezetők}

A sportesemények lebonyolításához az esetek többségében szükség van játékvezetőkre, pontozó bírókra, jegyzőkönyvvezetőkre. Ezt a tevékenységet magánszemélyként, vagy vállalkozóként akár egyéni akár társas vállalkozás keretei között végezhetik a szakemberek. Atipikus foglalkoztatásnak akkor minősül, ha magánszemélyként végzik. Ebben az esetben ezt az egyéb munkaviszonyra irányuló jogviszonyok közé sorolhatjuk, a játékvezetést és a játékvezetést segítő tevékenységeket, amelynek a jellemzője [16]:

- Formálisan nem minősül munkaviszonynak. Ugyanakkor a szabályozásuk hasonló a munkaviszonyhoz, hiszen valójában ezekben a jogviszonyokban is alárendeltségben történik a munkavégzés. A munkavégző jellemzően gazdaságilag nem önálló.

- Önálló jogiszabályozással rendelkeznek.

A játékvezetők és versenybírók foglalkoztatási szempontból az elöbb említetteken túl is speciális helyzetben vannak. A mérkőzéseket, versenyeket számos szinten, osztályban és céllal rendezik meg. Az elvárás minden esetben a verseny színvonalas lebonyolítása, a sport és versenyszabályzat betartása, a sportági ismeretek magas szintű ismerete.

A versenybírók és játékvezetők foglalkoztatását három alapvető típusba sorolható:

- szövetségi alkalmazás: a megbízó és kifizető is a sportági szövetség

- kirendelés: a megbízó, kirendelö a szövetség, a kifizető a sportszervezet

- sportszervezeti alkalmazás: a megbízó és a kifizető is a sportszervezet.

Az első típus, különösen a társasági adórendszeren keresztül támogatott sportágakban egyre gyakoribbá válik különösen a magasabb osztályban szerepelő csapatok játékvezetöi esetében. Ebben az esetben megbízási szerződést kötnek az érintettekkel a Polgári Törvénykönyv szabályozása szerint. Jogilag ugyanez a formája a harmadik típusnak is. A megbízási szerződés megkötése esetén két különböző adó és járulékfizetési lehetőség keletkezik.

- Az egyik lehetőség az egyszerüsített közteherviselési hozzájárulás szerinti adózás, amely a többek közt a sportszektorban jelent alacsonyabb közterhet. (A magánszemély jövedelméböl 2019-ben mindössze 15\% egyszerüsített közteherviselési hozzájárulást vonnak le.)

- A másik az önálló tevékenységre tekintettel történik a kifizetés, ez esetben nyilatkozat alapján legalább 10\%-os maximum $50 \%$-os költséghányad figyelembevételével történik az adó és járulék fizetés. (A magánszemélytöl a 2019-es szabályozás szerint személyi jövedelemadót, nyugdíjjárulékot, valamint egészségbiztosítási járulékot von le a kifizető.) 
Az érdekesebb eset a második típus, ahol a megbízó és kifizető eltérő szervezet. Ebben az esetben nem keletkezik társadalombiztosítási jogviszony. Ez azt jelenti, hogy a magánszemélyt kizárólag személyi jövedelemadó fizetési kötelezettség terheli és nincs nyugdíj- és egészségbiztosítási járulék. Igaz a játékvezető ebben az esetben is választhatja az EKHO szerinti adómegállapítást.

A játékvezetői, versenybírói díjakat az adott sportági szakszövetség határozza meg. A díjazás mértéke az esemény jellegétöl, osztályától függ. A Magyar Labdarúgó szövetség bajnoki évre határozza meg. A különböző osztályú mérkőzésekhez eltérő összeget rendel. A szabályzat eltérő játékvezetői és asszisztensi létszámot ír elő a különböző szintekhez. A szabályzatban elkülönítve nem szerepel egy-egy ember dijazása, hanem a csoportnak adható teljes összeg jelenik meg. Néhány példa ezek közül [28]:

- NBI férfi felnőtt nagypályás labdarúgó bajnokság esetén az összeg a 2019/20-as szezonban 1009500 Ft egy mérkőzés esetében. Ehhez kapcsolódik még 92800 Ft útiköltség átalány. Ebböl az összegböl kell fizetni a hat játékvezetőt, valamint a tartalék játékvezetőt és a játékvezető ellenőrt is.

- $\mathrm{NBI}$ női felnőtt korosztály esetében ugyancsak nagypálya esetében azonban csak 54340 forintot határoz meg a szabályzat. A hozzákapcsolódó útiköltség átalány $11600 \mathrm{Ft}$. Ebből a játékvezetőt és az asszisztenseket kell fizetni.

A díjazás ellenére az MLSZ különösen az amatör játékvezetők körében létszám problémákkal küzd. Az amatőr mérkőzések száma 2009-ról 2016-ra 3987-tel növekedett így elérte 11 173-as értéket. Addig ugyanezen időszak alatt az aktív játékvezetők száma 1062-vel csökkent, 2865 före. [24]

A Magyar Kézilabda Szövetség esetében egy före határozzák meg játékvezetői díjakat. A legfrissebb díjszabási táblázatuk 2019. augusztus 1-töl érvényes [26]:

- a legmagasabb játékvezetői díj az NB I.-es mérkőzések esetén található hétvégén és munkaszüneti napon $52000 \mathrm{Ft}$, míg munkanapon $68000 \mathrm{Ft}$

- a legalacsonyabb dij a szenior bajnokság esetén található ez 3500 Ft-ot jelent.

A Magyar Kosárlabdázók Országos Szövetsége továbbra is a sportszervezetekre hárítja a dijjak kifizetését. A sportágban történt játékos létszámnövekedést csak kis mértékben követte a játékvezetők létszámának növekedése a 2011/12-es szezonban lévő 441 föről a 2017/18-as szezonra 555 före emelkedett. [27]

\section{3. Önkéntesség}

Az önkéntes foglalkoztatás esetében két különböző lehetőség is adódik a sportrendezvényekhez kapcsolódva. Az egyik a közérdekü önkéntesség, a másik a közösségi szolgálat. A sportrendezvényeken mindkét típussal találkozhatunk. A közösségi szolgálatot nem minden esetben értelmezik önkéntességként. [19] Közösségi Szolgálat a középiskolai nappali képzésben résztvevő és az érettségi vizsgát 2016. január 1-jét követően megkezdő tanulók esetében az érettségi bizonyítvány kiállításának feltétele az 50 óra igazolása. Az önkéntesség fogalmi meghatározása szerint olyan tevékenység, melyet egyénileg vagy csoportosan, rendszeresen vagy alkalmanként, belföldön vagy külföldön a közös jó érdekében személyes akaratból végeznek anyagi ellenszolgáltatás nélkül. Az önkéntes tevékenység közvetlen anyagi haszonnal nem jár annak végzője számára, továbbá az önkéntes nem helyettesíti a fizetett munkaeröt. Az önkéntes nem elsősorban saját családjának segít, munkálkodása hozzáadott értékként jelenik meg a fogadó szervezet életében. A tevékenység megvalósulhat nonprofit, civilszervezet, vagy állami intézmény-, ritkább esetben for-profit szervezet (cégek, vállalkozások) keretein belül. [6] Az önkénes munka szabadidőhöz kapcsolódó tevékenység, a kifejezés latin elnevezéséhez kötődik: voluntarizmus, azaz szabadidöben szabadon választott foglalatosság. [12] A meghatározás alapján ugyan a közösségi szolgálat esetében nem beszélhetünk közvetlenül anyagi haszonról, azonban egyéb haszonszerzés megvalósul.

Önkéntes alapesetben bárkiből lehet, bárki végezhet a társadalom számára hasznos tevékenységet, amellyel nem csak az egyén fejlődik, hanem a közösség is fejlődik általa. Magyarországon önkénteseket föszabályként civil szervezetek foglalkoztathatnak. Ebbe a körbe 
tartozik az egyesület, az alapítvány és a civil társaság, amelynek legismertebb formája a nonprofit korlátolt felelősségü társaság. Az önkéntesek foglalkoztatására vonatkozóan azonban találkozhatunk egy joghézaggal hiszen minden civil szervezet fogadhat önkénteseket, amely esetben nincsenek kötelező elöírások a szerződéskötésre, juttatásra, bejelentésre. Ez kisebb események és szervezetek esetén nagy segítség, hiszen nem kell az adminisztrációval küzdeni. Az árnyoldala, hogy a foglalkoztatás a szürke zónában történhet. A közérdekű önkéntesek foglalkoztatása már szabályozottabb. Az erröl szóló törvény azonban korlátozza azoknak a szervezeteknek körét, akik fogadó szervezetként közérdekü önkéntes tevékenységre szervezhetnek önkénteseket. Egyesület és nonprofit társaság esetében feltétel a közhasznú besorolás.

Ami fontos, hogy a közérdekü önkéntes foglalkoztatást be kell jelenteni. Azonban nem kell a segítőket egyenként bejelenteni. Az önkéntesek így nem kerülnek központi nyilvántartásba. A szervezet valójában csak a szándékot jelenti az ilyen típusú szerződésre, majd a létszámot. $A z$ önkéntes szerződés formai szempontból létrejöhet írásban, szóban és ráutaló magatartással is. Kötelező az írásba foglalás, ha az időtartama meghaladja a tíz napot. Szintén írásba kell megkötni, ha a magánszemély juttatásban részesül. Ha az önkéntes tevékenységet szerződésbe foglalják kevésbé merülhet fel a fekete foglalkoztatás kétsége. Míg hazánkban a munkavégzés korhatára alapesetben 16 év az önkéntes tevékenység esetében ez 10 év.

A díjazás esetében figyelni kell arra, hogy a tevékenység ellátása érdekében szükséges utazás, szállás, étkezés biztosítása vagy költségek megtérítése nem automatikusan a fogadó szervezet kötelessége, de akár az is lehet. Az önkétes kaphat ellenszolgáltatást, amelyet nem terhel adó és járulékfizetési kötelezettség. Ezek az ellenszolgáltatásnak nem minősülő juttatások:

munkaruházat, védőfelszerelés és védőanyag

utazás, szállás, étkezés

védőoltás, szürővizsgálat és más betegségmegelőző szolgáltatás

iskolarendszeren kívüli képzés költsége

állat élelmezésének, ellátásának, képzésének biztosítása

eszköz müködtetéséhez szükséges feltételek biztosítása

élet, egészség- felelősségbiztosítás

jutalom (éves összege a mindenkori havi minimálbér maximum 20\%-a)

Az önkéntesség a sportszektor egyik jellemzője. Az önkéntes területen felállított struktúrák és ügynökségek nagyban hozzájárulnak a sportágazat müködtetéséhez. [1] A sporteseményeken való önkéntesség a fiatalok esetében az új típusú önkéntességhez sorolható. Ami azt foglalja magában, hogy fiatalok azért végeznek önkéntes tevékenységet, hogy beleírhassák az önéletrajzukba, és az ezzel szerzett tudást és kapcsolati tőkét a későbbiekben anyagi javakra fordíthassák. [11] Egy kiemelt sportrendezvényen dolgozó személy számára a leggyakrabban előforduló motivációs tényező a nemzeti büszkeség, az országa iránti tenni akarás, a társadalmi kapcsolatok erősítése, a barátságok kötése. [20] A magyar sportegyesületekben végzett kutatás szerint a sport területén két csoportra bonthatjuk az önkénteseket. Az idősebb generáció tagjait, a sport jellemzően a saját sportáguk iránti elköteleződés vezérli. Az a céljuk, hogy az általuk szeretett sportágban legyenek követőik, legyenek eredmények. A fiatalok esetében a közösségi élmény, a kapcsolatteremtés lehetősége számít. Az ő elköteleződésüket az élmény táplálja. [5]

A Központi Statisztikai Hivatal a 2014-es év vonatkozásában közölt adatokat az önkéntes munka és a háztartási munka vonatkozásában. A felmérés szerint legtöbben házi- és házkörüli munkát végeztek a saját háztartásukon kívül élö személy számára. Ez több mint egymillió főt jelent. A sport és szabadidős tevékenység keretében ez 129 ezer fö végzett önkéntes tevékenységet. Ezen belül kicsit magasabb, mint $20 \%$ a rendszeresen ilyen tevékenységet végzők aránya, míg a többség alkalmanként választja. [23]

A sportszektor Magyarországon is jelentősen támaszkodik az önkéntesek munkájára. A sport stratégia ágazattá emelése mellett, a kormány az elmúlt időszakban a nemzetközi sportesemények rendezését is prioritásként kezelte. A változást jól szemlélteti, hogy míg 2010-ben 34 kormány által támogatott nemzetközi sportesemény került megrendezésre, addigra ez a szám 2017-re 109-re emelkedett. [21] A 2017-es események közül kiemelkedik a 17. FINA Világbajnokság (Vizes VB), amelyet Magyarországon két helyszínen Budapesten és Balatonfüreden rendeztek meg. A foglalkoztatáshoz kapcsolódóan a következő adatok ismertek: a verseny lebonyolításának naponta 
az önkénteseken kívül 1000 közremüködője volt. [18] Az önkéntesek létszáma 3500 fö körül mozgott, melyböl 2500 a FINA Világbajnokságon, míg közel 1000 fő a Masters Világbajnokságon tevékenykedett. [2] Ennél kisebb esemény, de több mint száz önkéntes dolgozott a budapesti kvalifikációs öttusa világbajnokságon 2019-ben. Az önkéntességnek a turizmusra gyakorolt hatása is jelentős, különösen a tömegrendezvények esetében [22] Mára már elterjedt a „volunter tourism” (önkéntes turizmus) jelensége. Az emberek előszeretettel kapcsolják össze nyaralásukat valamilyen karitatív tevékenységgel, jellemzően rászorulóknak segítenek, vagy környezetvédelmi akciókhoz csatlakoznak. [4] Ennek egyik formája lehet a sporteseményekhez, különösen a mega sporteseményekhez köthető turizmus. A megaesemények szervezői tisztában vannak ezzel, ezért nagymértékben támaszkodnak is az önkéntes munkaeröre. [8] Az események sikeressége függ ezen emberek munkájának minőségétöl. Jellemzően emiatt minden helyszínen külön figyelmet szentelnek rájuk. [3] Az Olimpiák esetében szintén hatalmas érdeklődés a tevékenység iránt. A riói olimpiára akkora volt az érdeklődés, hogy a 240 ezer jelentkezőböl választották ki azt az 50 ezer önkéntest, aki segítette az esemény lebonyolítást. [22]

\section{Egyszerűsített foglalkoztatás}

Az egyszerüsített foglalkoztatásról szóló törvény egyik célja az, hogy a rövid időre létesített munkaviszony adminisztrációs, valamint adózási és járulékterheit csökkentse. Rugalmasabb munkajogi szabályok mellett lehet teljesíteni a jogszabályi kötelezettségeket. [7] A foglalkoztatási forma népszerüsége, az elmúlt években folyamatosan emelkedett. A különböző típusok adatait 2. táblázat tartalmazza. A sportesemények esetében az egyetlen forma az alkalmi munkavégzés lehet, amely a szabályozás szerint maximum öt egymást követö naptári nap lehet. Ezenkívül még szabályozzák a havi (15 nap) és az éves (90 nap) maximális munkavégzés mennyiségét. A jogviszony különlegessége, hogy nem a szerződés megkötéssel, hanem a bejelentés megtételével jön létre. Hatályos szabályozás szerint ügyfélkapun és telefonos applikáció segítségével is megtörténhet a bejelentés. Ennél a foglalkoztatási típusnál kizárólag a foglalkoztatót terheli kötelezettséget. A foglalkoztatottól sem adót, sem járulékot nem vonnak. Az óránként, valamint a naponként járó juttatást a minimálbérhez kötik.

2. táblázat Egyszerüsített foglalkoztatottak átlagos havi létszáma (egy fö csak egyszer szerepel egy hónapban),

\begin{tabular}{l|rrrr} 
Megnevezés & $\mathbf{2 0 1 4}$ & $\mathbf{2 0 1 5}$ & $\mathbf{2 0 1 6}$ & $\mathbf{2 0 1 7}$ \\
\hline Mezögazdasági idénymunka & 45784 & 43692 & 42698 & 41247 \\
Turisztikai idénymunka & 2325 & 2845 & 3321 & 3933 \\
Alkalmi munka & 146139 & 165616 & 181062 & 203334 \\
Filmipari statiszta & 1249 & 1757 & 2130 & 1964 \\
Összesen & $\mathbf{1 9 5} 497$ & $\mathbf{2 1 4} \mathbf{1 8 0}$ & $\mathbf{2 2 9 2 1 1}$ & $\mathbf{2 5 0 4 7 8}$
\end{tabular}

Forrás: Nemzeti Adó- és Vámhivatal [25]

A szabadidősport rendezvényeken csakúgy, mint a verseny rendszerben lebonyolított eseményeknél jellemző, hogy az esemény napján lényegesen több segitöre, munkatársra van szükség, mint az azt megelőző időkben. A nemzetközi eseményekkel kapcsolatban már bemutatásra került, hogy milyen létszámmal dolgoznak a rendezvény ideje alatt. $A$ nemzetközi sportesemények vagy kisebb egyesületek által rendezett alkalmak esetében az önkéntesek bevonása a legelterjedtebb. A nagy szabadidősport rendezvények esetében, amelyeket gazdaság társaságok bonyolítanak le nincs lehetőség erre. Ebben az esetben számukra az egyszerüsített foglalkoztatás lehetősége marad.

A legnagyobb szabadidősport rendezvényeket lebonyolító szervezet Magyarországon Budapest Sportiroda Kft, melynek a számviteli beszámolója szerint 2018-ban mindösszesen 23, míg azt megelőző két évben 24 fő volt az átlagos foglalkoztatotti létszáma. A legnagyobb rendezvényük 
közül az egyik az őszi maraton fesztivál, ahol a résztvevői létszám harmincezer fö felett van. Az útvonalon tizenkét frissítőállomás müködik, amely többek közt nagyságrendileg 60000 liter vízzel segíti a teljesítést. Azaz az eseményen a foglalkoztatotti létszám többszáz föt jelent. [10]

\section{Következtetések}

Az elmúlt időszakban a magyarországi sportszektor jelentős átalakuláson ment keresztül finanszírozási szempontból a versenysport területén. A pénzügyi források bövülésének köszönhetően növekedtek a sportolói és a foglalkoztatotti létszámok az ágazatban. A kormányzati támogatásnak köszönhetöen jelentősen megnövekedett a megrendezésre kerülő sportesemények száma. A sportesemények lebonyolítása, különösen az esemény időpontjában, illetve a közvetlenül azt megelőző és követő időszakban jelentős munkaerő többletet igényel. Ennek a munkaerőnek a foglalkoztatása jellemzően atipikus keretek közt zajlik. A tanulmányban a leggyakrabban elöforduló típusok úgymint az önkéntesek, a játékvezetők, és a segítők foglalkoztatási formái kerültek bemutatásra. A sportszektorban, ezen belül a sporteseményeken alkalmazottak segítők és szakemberek esetében eltérő humánerőforrás feladatok jelentkeznek, mint a hagyományos munkavégzés során. Ezeken az eseményeken néhány napra, maximum pár hétre kell hatalmas munkaerő mennyiséget toborozni azt megfelelően szervezni, motiválni a törvény adta kereteken belül.

\section{Irodalomjegyzék}

[1] Adams A., Dean J. (2009) Exploring formal and informal dimensions of sports volunteering in England, European Sport Management Quarterly Vol 9. No. 2 Groningen, The Netherlands; 119-140.

[2] Balogh Z. (2017): Vizes $\mathrm{Vb}-3500$ önkéntes lesz jelen a rendezvényen, https://sportmonitor.info/?p=30887

[3] Baum T., Lockstone L. (2007): Volunteers and mega sporting events: developing a research framework. International Journal of Event Management Research. 3.1 29-41

[4] Boluk, K., Kline C., Stroobach (2017): Exploring the expectations and satisfaction derived from volunteer tourism experiences. Tourism and Hospitality Research 17.3. 29-41

[5] Bukta Zs. (2013): Új kihívások a sport civil szférájában. Megfelelnek-e a sportegyesületek a közösségi igényeknek. Andragógia és müvelödéselmélet. I/1 72-87

[6] Czike K., Bartal A. (2005): Önkéntesek és nonprofit szervezetek - az önkéntes tevékenység motivációi és szervezeti típusok az önkétesek foglalkoztatásában. Acta Civitalis 2005.

[7] Ember Alex (2014): Atipikus munkaviszonyok in: Hajdú József - Kun Attila szerk: Munkajog, Szegedi Egyetem - Patrocinium Kft, 271-302.

[8] Farkas K., Hegedűs A., Katona B., Máhl Zs., Mátyus A., Molnár Á. K. (2012): Előtérben a háttér - az önkéntesség Magyarországon. Vezetéstudomány 43.4 62-67.

[9] Ferencz J. (2015): Atipikus foglalkoztatási formák. Dialóg Campus Kiadó. 179.p.

[10] Félmilliárd Futólépés Budapesten, Tények és számok (2019), BSI; https://www.spar.hu/sajtokapcsolat/2019/felmilliard-futolepesbudapesten

[11] Fényes H. (2015): Önkéntesség és új típusú önkéntesség a felsőoktatási hallgatók körében. Debreceni Egyetemi Kiadó, 23 p.

[12] Fényes H.,Kiss G. (2011): Az önkéntesség szociológiája. Kultúra és közösség 2.2. 35-47

[13] Finna, H., Gyökér I. (2009): Hazai KKV-k atipikus foglalkoztatási gyakorlata. Vezetéstudomány XI. évf. különszám. 36-42.

[14] Finna H., Forgács, T. (2010): A rugalmas munkavégzési formákról. Információs Társadalom 2010/1. 77-94

[15] Gősi Zs. (2017): Atipikus foglalkoztatási formák sportszervezeteknél. Köztes Európa, Társadalomtudományi folyóirat: A VIKEK közleményei. 9:1-2. 137-145

[16] Gyulavári T. (2014): A szürke állomány; Gazdaságilag függő munkavégzés a munkaviszony és az önfoglalkoztatás határán. Budapest, Pázmány Press.

[17] Hegyi L. (2019): Tipikus és atipikus foglalkoztatás, munkaviszony és önfoglalkoztatás. Dél-Alföldi JOGpontok 56 p.

[18] Koroknay Zs., Müller A., Bíró M. (2018): A 17. FINA Vizes Világbajnokság sport, társadalmi és gazdasági hatásai. In. Válogatott tanulmányok a sporttudomány köréböl 1. szám. 115-128

[19] Markos Valéria (2016): Közösségi szolgálat vagy önkéntesség; Educatico XXV.Évf 3. szám; 444-450.

[20] Minnhaert L. (2012): An Olympic legacy for all? The non-infrastructural outcomes of the Olympic Games for socially excluded groups. Tourism Management. 33.2 361-370

[21] Stocker, M.\& Szabó, T.(2017): A hazai sportirányítás szerepe és tevékenysége a kiemelt hazai sportesemények esetében. in. szerk: Szmodits, M.; Szőts, G.: A sportirányítás gazdasági kérdései 2017, Budapest, Magyar Sporttudományi Társaság 91-108

[22] Szenyéri V., Michalkó G., Anestis F. (2019): A FINA Világbajnokság (2017) önkénteseinek szerepe Budapest sportturizmusában. Földrajzi Közlemények 143.1. 12-23 
[23] Váradi R. (2017): Az önkéntes munka jellemzői a munkaerő-felmérés alapján. In. Háztartási munka, önkéntes munka, láthatatlan munka, I. Konferenciakötet. Budapest, KSH 66-89

http://www.ksh.hu/docs/hun/xftp/idoszaki/pdf/lathatatlan_munka_1.pdf\#page=66

[24] Wenzel I. (2017) Tájékoztatás a játékvezetői helyzetről. Elöadás: 2017.05.19. http://ugodse.hu/hirek/17_18megyei/wenczel_imre tajekoztato.pdf

[25] Jelentés 2019-ben egyszerüsített foglalkoztatás keretében foglalkoztatottak számáról. https://kozfoglalkoztatas.kormany.hu/download/4/08/52000/EFO\%20jelent\%C3\%A9s_port\%C3\%A1lra_2019 0108.pdf

[26] Játékvezetői díjak, Magyar Kézilabda Szövetség 2019/2020 https://www.keziszovetseg.hu/v2h/003/013/p_013.asp?p_bizottsag_kod=8

[27] MKOSZ küldöttgyülés 2018.05.22.

http://img.hunbasket.webpont.com/art/orig/50466_mkoszkuldottgyules2018irasosanyagok.pdf

[28] Szabályzatokhoz kapcsolódó díjfizetési rend 2019/2020-as szezon, MLSZ http://dokumentumtar.mlsz.hu/02 Szabalyzatok/02 Labdarugas uzemeltetesi szabalyzatok/01 Versenyeztete si szabalyzatok/DR/2019-2020.\%20\%C3\%A9vi\%20D\%C3\%ADjfizet\%C3\%A9si\%20Rend.pdf

[29] 2005. évi LXXXVIII. törvény; A közérdekü önkéntes tevékenységröl

[30] 2010. évi LXXV. törvény; Egyszerüsített foglalkoztatás

[31] 2012. évi I. törvény; Munkatörvénykönyve

[32] 2013. évi V. törvény; Polgári törvénykönyv

[33] 1995. évi CXVII. törvény a személyi jövedelemadóról

[34] 1997. évi LXXX. törvény a társadalombiztosítás ellátásaira a magánnyugdíjra jogosultakról, valamint e szolgáltatások fedezetéröl

[35] 2005. évi CXX. törvény az egyszerüsített közteherviselési hozzájárulásról 